\title{
Flow cytometric DNA content analysis of fibropapillomas in green turtles Chelonia mydas
}

\author{
George P. Papadi ${ }^{1}$, George H. Balazs ${ }^{3}$, Elliott R. Jacobson ${ }^{2}$

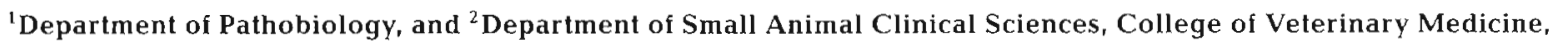 \\ University of Florida, Gainesville, Florida 32610, USA \\ ${ }^{3}$ Southwest Fisheries Science Center, Honolulu Laboratory, National Marine Fisheries Service, Honolulu, \\ Hawaii 96822-2396, USA
}

\begin{abstract}
In an attempt to characterize biologic properties of green turtle fibropapillomatosis (GTFP), blood cells, dermis of normal skin, dermis of cutaneous fibropapillomas, and visceral fibroblastic nodules of green turtles Chelonia mydas with cutaneous fibropapilloma were examined by flow cytometry. DNA of each sample was stained with propidium iodide and histograms were recorded utilizing a FACSCAN flow cytometer. All samples examined had similar histograms, indicative of normal cell cycles and diploid profiles. Small $S$ phase and $G_{2} M$ fractions $(<5 \%)$ indicated a low mitotic activity and a nonproliferating state. Statistical analyses were performed on the coefficient of variation (CV) of the $G_{1}$ peak for the various tissues analyzed. The mean $C V$ for blood from all the unaffected turtles was 3.21 while that from turtles afflicted with GTFP was 3.43. CVs of normal skin from healthy turtles and turtles afflicted with GTFP were 4.25 and 4.41 respectively. The mean CV for fibropapillomas was 5.27 , a number which, though higher than either blood or normal skin, probably reflects the difference in stain uptake characteristics between fibropapillomas and the other 2 tissues rather than any inherent DNA or ploidy difference.
\end{abstract}

KEY WORDS: Fibropapilloma - Flow cytometry Green turtle $\cdot$ Chelonia mydas

\section{INTRODUCTION}

The first reports of green turtle fibropapillomatosis (GTFP) were in the 1930s, with descriptions of cutaneous tumors in green turtles Chelonia mydas collected in the Florida Keys, USA (Lucké 1938, Smith \& Coates 1938). In the early 1980s numerous observations of GTFP were made worldwide including in the Indian River Lagoon system of east-central Florida (Ehrhart 1991), the Florida Keys (Teas 1991), Hawaii, USA (Balazs 1991), and at near-shore sites in Puerto Rico, Cayman Islands, Virgin Islands, Barbados, Venezuela, Colombia, Panama, Belize, and Australia (Jacobson 1991). The causative agent of GTFP or the environmental insult responsible for its development has not yet been elucidated. While spirorchid trematode eggs (Jacobson et al. 1989) and a herpesvirus (Jacobson et al. 1992) have been observed in GTFP, the role of these potential pathogens in GTFP is still unclear. Recent evidence has indicated an infectious agent sucessfully transmitted between green turtles which was reported to be obtained from papillomaderived cell-free suspensions (Herbst et al. 1995)

Although fibropapillomas are considered benign tumors, the disease can be life-threatening. Corneal and or scleral involvement in turtles is common and often results in blindness (Brooks et al. 1994). Turtles with tumors of large size and numbers may become entangled in nets and drown or may not be able to swim and feed normally. Visceral tumors, particularly in the lungs and kidney, have also been diagnosed (Norton et al. 1990, Jacobson 1991). Since these tumors appear benign histologically, their multicentric expression is likely caused by factors acting on a systemic level. Still, the etiology of these tumors needs further investigation.

Flow cytometry has its origins in the 1930s when the first investigators attempted to count cells while in flow, utilizing a photoelectric apparatus attached to the ocular of a microscope (Moldavan 1934). As a continu- 
ation of this work, Wallace Coulter developed the first 'Coulter Counter', which allowed particles in a fluid to be counted (Coulter 1956). Coulter Counters are currently used throughout the world to determine the numbers of red blood cells in a unit volume of blood. Over the last 25 yr, flow cytometry has developed into a sophisticated tool for rapidly quantitating multiple chemical and physical properties of individual cells or cell constituents of heterogeneous populations of cells. Flow cytometry has extremely varied applications including discrimination of lymphocyte subsets utilizing surface-antigen-specific monoclonal antibodies, measurement of cell cycle kinetics, counting blood cells, measuring intracellular ion concentrations, and measurements of chromosomal karyotype and cell proiiferation (Mielamed el al. 1990) One of line celiular components that can be measured is DNA content This has been utilized in both human and veterinary medicine to help characterize biologic properties of tumors (Raber \& Barlogie 1990). By determining the DNA content of the cellular populations comprising a tumor, ploidy status can be determined. In evaluating human solid tumors, aneuploidy is one accepted marker for the malignant cell population (Barlogie et al. 1980).

Using flow cytometry, the amount of DNA within a nucleus can be determined by use of fluorescent dyes that bind stoichiometrically, with fluorescence intensity emitted by each cell proportional to its DNA content. Accumulating DNA content data on several thousand nuclei allows one to graphically depict cell populations as a histogram. In a population of slowly or non-proliferating cells, the majority are within the $\mathrm{G}_{0} / \mathrm{G}_{1}$ (presynthetic) phase of growth and exhibit a single narrow peak on the histogram.

In an attempt to better understand the etiology of GTFP, blood and biopsies of tumors and normal skin from affected and normal turtles were obtained and examined by flow cytometry. The results of this study are reported below.

\section{MATERIALS AND METHODS}

Blood was obtained from 6 and 11 green turtles Chelonia mydas respectively in Bermuda and Panama. Five of the samples from Panama were obtained from turtles with GTFP and 6 were from clinically healthy turtles. The 6 turtles collected in Bermuda were clinically healthy. From Hawaii, 6 blood samples and 6 biopsies of normal skin from 6 clinically healthy turtles, and 7 blood samples and 7 biopsies of normal skin and fibropapillomas from 7 affected turtles were obtained. From Florida, 5 normal skin biopsies and 5 fibropapillomas were obtained from 5 affected green turtles which were submitted to the University of Florida for necropsy. In 6 turtles with visceral nodules, up to 4 nodules from each turtle were also evaluated. Biopsies of fibropapillomas from 6 additional turtles in Florida were obtained from field cases.

Seventeen blood samples from Bermuda and Panama were collected and stored in heparinized glass tubes, immediately frozen and transported frozen to the University of Florida. Blood samples from Hawaii were collected and stored in lithium heparin microtainer tubes and shipped on dry ice. Solid cutaneous tissue samples were collected with $6 \mathrm{~mm}$ biopsy punches, wrapped in saline-soaked gauze, frozen immediately and shipped on dry ice. All blood samples were collected in lithium microtainer tubes. Solid tissues were transported in either saline-soaked gauze or in cryotubes and shipped on cold packs. Upon receipt, al. samples were immediately frozen at $-80^{\circ} \mathrm{C}$. From each turtle with GTFP, portions of cutaneous and visceral tumors were fixed in neutral buffered $10 \%$ formalin and routinely processed for light microscopy. Sections were cut at $6 \mu \mathrm{m}$ and stained with hematoxylin and eosin (H\&E)

Cells harvested from the dermis of normal skin and fibropapillomas, and from the core of visceral nodules, were obtained by scraping the frozen samples for 3 to 5 min with a no. 10 scalpel blade and collecting the cells into $1 \mathrm{ml}$ aliquots of Hanks buffer (Gibco BRL, Gaithersburg, MD, USA). Cell concentrations from solid tissues were measured on a hemocytometer using $30 \mu \mathrm{l}$ of cells from solid tissues which were stained with $70 \mu \mathrm{l}$ of a propidium-iodide-based fluorescent solution (Cycle Test Kit; Becton Dickinson, Immunocytometry Systems, San Jose, CA, USA). For blood samples, $10 \mu \mathrm{l}$ of cells were stained with $90 \mu \mathrm{l}$ propidium iodide solution. The concentrations were adjusted to between 500000 and 2500000 cells per $\mathrm{ml}^{-1}$. Each sample of cells was then centrifuged in a $1.5 \mathrm{ml}$ microcentrifuge tube at between 200 and $300 \times$ $g$, a force mild enough to avoid clumping but high enough to remove much of the debris. The supernatant was aspirated making sure not to expose the cells to the air. Following resuspension with $1 \mathrm{ml}$ of Hanks buffer, the samples were filtered through $40 \mu \mathrm{m}$ nylon mesh to remove the large clumps, followed by slow centrifugation at 200 to $300 \times \mathrm{g}$. Next the samples were resuspended in 50 to $100 \mu$ of Hanks buffer Samples were then processed with a Becton Dickinson. Cycle Test DNA Reagent Kit, which is based on the method of Vindelov in which cells are dissociated with trypsin followed by fluorescent staining with propidium iodide (Vindelov \& Christensen 1990). Nuclear fluorescence was measured with a FACSCAN (Becton Dickinson) flow cytometer. The flow cytometer was calibrated with alcohol-fixed 
blood cell nuclei from chickens, and with blood cell preparations from green sea turtles which were considered to be clinically normal. The $G_{1}$ peak of the DNA histogram was adjusted to channel 200. Data were collected for up to 20000 cells per sample. A. Consort 30 computer system running Cell-Fit software (Becton Dickinson) was used to collect and analyze the data using the 'RFIT' model.

The coefficient of variation (CV) for the $G_{1}$ peaks of the histograms were determined for the various tissues examined. Two sample $t$-tests were used to compare the mean CV value for nuclei obtained from: (1) blood cells of clinically healthy green turtles and those with fibropapillomas and (2) the dermis of normal skin and those obtained from the dermis of fibropapillomas. Among the affected turtles, analysis of variance was used to compare the mean CV for the $G$, peaks of different tissue types, with Bonferroni's multiple comparison procedure used to determine which specific groups differed. A 2-way analysis of variance was performed to compare mean $\mathrm{CV}$ for the $\mathrm{G}_{1}$ peaks of fibropapillomas obtained from Florida and non-Florida green turtles.

\section{RESULTS}

The light microscopic appearance of all cutaneous tumors was consistent with that reported for GTFP (Jacobson et al. 1989). The visceral nodules were composed of masses of proliferating fibroblasts and were similar to those previously described for green turtles with GTFP (Schlumberger \& Lucké 1948, Norton et al. 1990)

All samples examined had similar histograms, indicative of normal diploid profiles (Fig. 1). The $G_{1}$ peak was the major peak for all samples examined. In all samples the $S$ phase was found to be a small component of the DNA profile $(0.1$ to $3 \%)$. The $\mathrm{G}_{2} \mathrm{M}$ peaks for all samples examined were also small or nonexistent.

No significant differences were found $(p=0.38)$ when the $C V$ of the $G_{1}$ peaks for blood cells for normal turtles $(3.21 \%)$ and those with GTFP (3.43\%) were compared (Table 1). The $\mathrm{CV}$ for the $\mathrm{G}_{1}$ peak of blood cells obtained from Florida green turtles showed greater variability than those from other locations. No
Fig. 1 Chelonia mydas. Histograms (relative no. of cells versus relative DNA content as measued by fluoresence intensity) of tissues from healthy green turtles and green turtles with GTFP. (A) Blood from a healthy Hawaiian green turtle. (B) Blood from a Hawaiian green turtle with GTFP. (C) Normal skin from a healthy Hawaiian green turtle. (D) Normal skin from a Hawaiian green turtle with GTFP. (E) Fibropapilloma from a Hawaiian green turtle with GTFP. (F) Cardiac stomach nodule from a Florida green turtle with GTFP

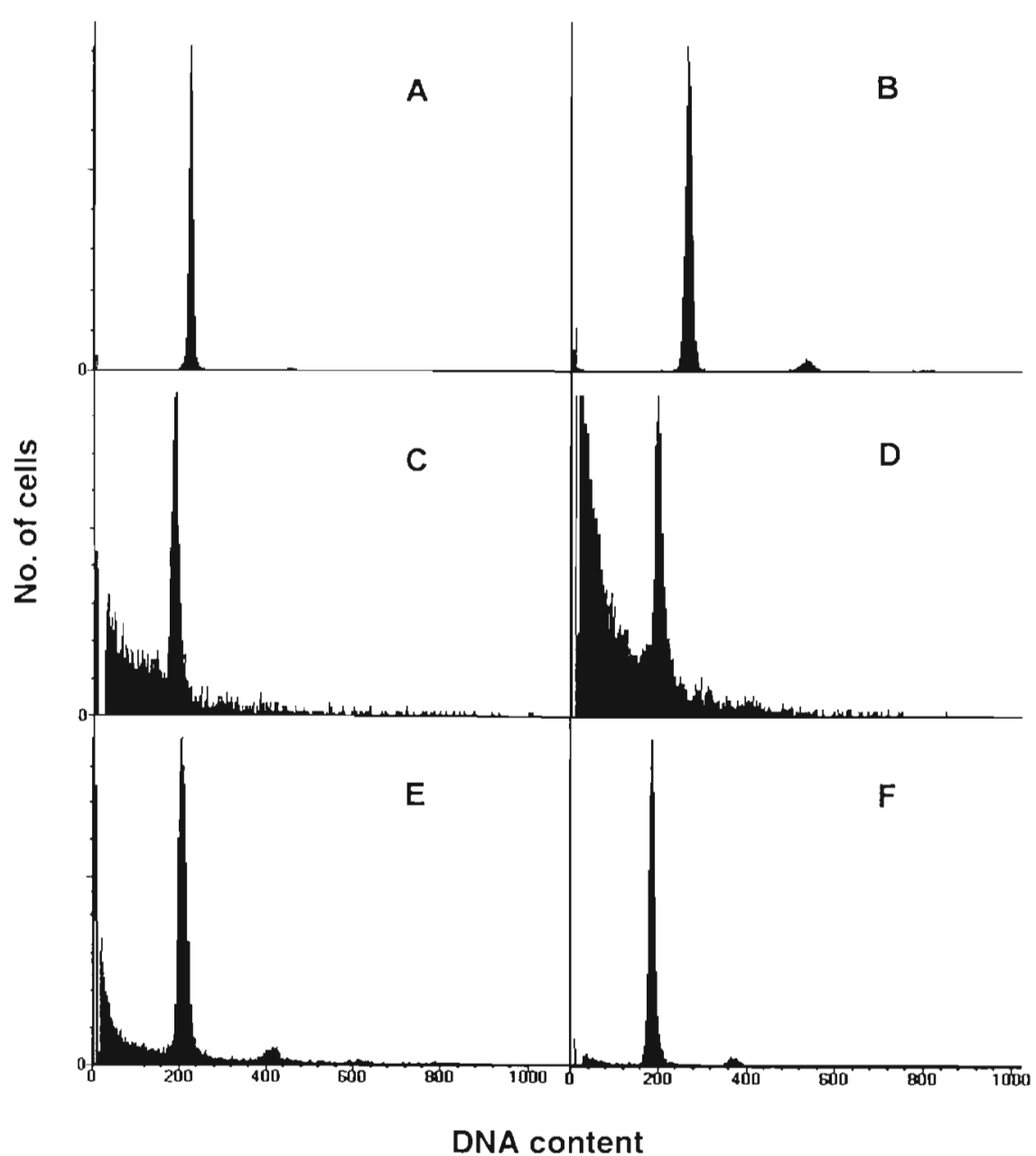


Table 1 Chelonia mydas. Comparison of GTFP-affected and unaffected turtle coefficient of variation (CV) values for different tissue types. A 2-sample $t$-test was used to determine whether the mean $(\mu) \mathrm{CV}$ value differed for the 2 groups of turtles. The results showed that there was no significant difference $(t=-0.898, p=0.378$ for blood and $t=-0.394, p=0.701$ for normal skin). CI: $95 \%$ confidence interval

\begin{tabular}{|c|c|c|c|c|c|c|c|}
\hline Sample & Health status & $\begin{array}{l}\text { No. of turtles } \\
\text { examined }\end{array}$ & $\begin{array}{c}\text { Mean } G_{1} \\
C V\end{array}$ & $\mathrm{CI}$ & $\mathrm{SD}$ & SE & $p$-value \\
\hline Blood & $\begin{array}{l}\text { Normal } \\
\text { Fibropapilloma }\end{array}$ & $\begin{array}{l}18 \\
21\end{array}$ & $\begin{array}{l}3.21 \\
3.43\end{array}$ & $\begin{array}{l}3.03<\mu<3.39 \\
2.96<\mu<3.89\end{array}$ & $\begin{array}{l}0.36 \\
1.02\end{array}$ & $\begin{array}{l}0.09 \\
0.22\end{array}$ & 0.38 \\
\hline $\begin{array}{l}\text { Normal } \\
\text { skin }\end{array}$ & $\begin{array}{l}\text { Normal } \\
\text { Fibropapilloma }\end{array}$ & $\begin{array}{l}5 \\
8\end{array}$ & $\begin{array}{l}4.25 \\
4.41\end{array}$ & $\begin{array}{l}3.49<\mu<5.01 \\
3.76<\mu<5.06\end{array}$ & $\begin{array}{l}0.61 \\
0.78\end{array}$ & $\begin{array}{l}0.28 \\
0.28\end{array}$ & 0.70 \\
\hline
\end{tabular}

significant difference $(p=0.70)$ was found when the $\mathrm{CV}$ of normal skin from all normal green turtles was compared to normai appearing skin from iurtiles with GTFP (Table 1). The mean CVs of the $G_{1}$ peak for nuclei obtained from fibropapillomas in green turtles in Hawaii and Florida were 4.88 and $5.66 \%$ respectively (Table 2). With the exception of gastric nodules in 2 turtles, visceral nodules in the lungs, kidneys, and liver produced a mean CV of $3.0 \%$.

When the $C V$ of the $G_{1}$ peak of blood, normal skin, and the dermal portion of cutaneous fibropapillomas from all turtles with GTFP were analyzed using a 1-way analysis of variance, significant differences ( $p \leq 0.0001)$ were found, fibropapillomas having noticeably higher CVs (Table 3). Significant effects due to geographic origin and tissue type were also detected (Table 4). Blood samples from Florida had significantly higher CVs than from either Hawaii or Panama. Fibropapillomas had CVs which were significantiy nigher than those from normal skin which were higher than those from blood. A test for interaction between these 2 factors was performed; this was not statistically significant.

\section{DISCUSSION}

In this report both normal chicken and green sea turtle blood cells were used as internal controls to help identify the position of the diploid $\mathrm{G}_{0} / \mathrm{G}_{1}$ population of cells. Since red blood cells of birds and reptiles are nucleated, blood is a convenient tissue to use in this calibration

Table 2. Chelonia mydas. Mean $(\mu) \mathrm{CV}$ values for the $\mathrm{G}_{1}$ peak of the DNA histograms, by tissue type, geographical region, and the absence or presence of fibropapillomas. Where duplicates of the same tissue from 1 turtle were run, the average of the CV values was used. CI: $95 \%$ confidence interval ${ }_{i}$ nd: not determined

\begin{tabular}{|c|c|c|c|c|c|c|c|}
\hline \multirow[t]{2}{*}{ Sample } & \multirow[t]{2}{*}{ Location } & \multicolumn{3}{|c|}{ Fibropapilloma turtle } & \multicolumn{3}{|c|}{ Normal turtle -} \\
\hline & & $\begin{array}{l}\text { No. of turtles } \\
\text { examined }\end{array}$ & $\begin{array}{c}\text { Mean } G_{1} \\
C V\end{array}$ & $\mathrm{CI}$ & $\begin{array}{l}\text { No. of turtles } \\
\text { examined }\end{array}$ & $\begin{array}{c}\text { Mean } G_{1} \\
C V\end{array}$ & $\mathrm{CI}$ \\
\hline \multirow[t]{4}{*}{ Blood } & Bermuda & nd & & & 6 & 3.57 & $3.33<\mu<3.76$ \\
\hline & Panama & 5 & 2.86 & $2.57<\mu<3.15$ & 6 & 3.15 & $2.88<\mu<3.42$ \\
\hline & Hawaii & 7 & 2.93 & $2.58<\mu<3.27$ & 6 & 2.92 & $2.58<\mu<3.27$ \\
\hline & Florida & 9 & 4.13 & $3.18<\mu<5.07$ & nd & & \\
\hline \multirow[t]{2}{*}{ Normal skin } & Hawaii & 3 & 4.50 & $2.02<\mu<6.98$ & 5 & 4.24 & $3.49<\mu<5.01$ \\
\hline & Florida & 5 & 4.36 & $3.44<\mu<5.28$ & nd & & \\
\hline \multirow[t]{2}{*}{ Fibropapillomas } & Hawali & 6 & 4.88 & $3.70<\mu<6.07$ & nd & & \\
\hline & Florida & 8 & 5.66 & $4.79<\mu<6.32$ & nd & & \\
\hline $\begin{array}{l}\text { Visceral } \\
\text { nodules in: }\end{array}$ & Florida & \multicolumn{2}{|c|}{ nodules in: } & & & & \\
\hline Lung & & $2(4)^{a}$ & 3.40 & $2.57<\mu^{\mathrm{b}}<5.67$ & nd & & \\
\hline Kidney & & $1(2)$ & 2.80 & & nd & & \\
\hline Liver & & $1(1)$ & 2.80 & & nd & & \\
\hline Stomach & & $2(3)$ & 6.30 & & nd & & \\
\hline
\end{tabular}


Table 3. Chelonia mydas. Comparison of $\mathrm{CV}$ values $(\%)$ of different tissue types (ANOVA, p $\leq 0.0001$ ) of green turtles with GTFP. CI: $95 \%$ confidence interval; $\mu$ : mean

\begin{tabular}{|lccccc|}
\hline Sample & $\begin{array}{c}\text { No. of turtles } \\
\text { examined }\end{array}$ & $\begin{array}{c}\text { Mean } G_{1} \\
\text { CV }\end{array}$ & CI & SD & SE \\
\hline Blood & 21 & 3.31 & $2.96<\mu<3.89$ & 1.02 & 0.22 \\
Normal skin & 8 & 3.41 & $3.76<\mu<5.06$ & 0.78 & 0.78 \\
Fibropapilloma & 14 & 5.33 & $4.69<\mu<5.97$ & 1.11 & 0.30 \\
\hline
\end{tabular}

In evaluating and interpreting the histograms of tissue, the $\mathrm{CV}$ is one of the most important criteria (Dressler \& Bartow 1989). It corresponds to the ability to resolve 2 peaks in the histogram. The smaller the numerical value, the better the resolving power. The greater the $\mathrm{CV}$, the wider the peak and the greater the chance of missing an abnormal population that lies close to $2 \mathrm{~N}$, the diploid state. $\mathrm{G}_{1} \mathrm{CVs}$ of $2 \%$ require a $4 \%$ difference in DNA in order to resolve a bimodal peak. CVs of $3 \%$ require a difference of $6 \%$ (Vindelov et al. 1983, Benson \& Braylan 1994). Histograms with CVs $<5 \%$ are generally considered acceptable (Dressler \& Bartow 1988).

When histograms of blood cells from normal green turtles were compared to those of green turtles with GTFP, no significant differences were found for the CVs of the $G_{1}$ peaks for the 2 groups. The CVs of the $G_{1}$ peaks were $<4 \%$. This suggests that blood cells from the turtles with GTFP had a normal cell cycle with nuclei having normal ploidy. Similarly, when normal skin obtained from normal green turtles was compared to normal skin from turtles with GTFP, both groups had normal cell cycles with comparable CVs $(<5 \%)$ for the $G_{1}$ peaks of their respective histograms. While histograms of blood, normal skin, and fibropapillomas from turtles with GTFP indicated a normal cell cycle, statistically significant differences were found when the CVs of the $G_{1}$ peaks for these histograms were compared. These differences, however, may reflect the stain uptake characteristics and the specific physical properties of the tis- sues rather than any inherent differences in their DNA.

Blood by its nature is a collection of dissociated cells unlike turtle skin and fibropapillomas which are composed of tightly interwoven cells. The procedures necessary to dissociate skin and fibropapillomas result in the production of relatively large amounts of debris which persists to some extent even after centrifugation with Hanks buffer. In histograms of normal skin and fibropapillomas, the irregular profiles to the left of the $G_{1}$ peaks are caused by debris from sample collection. Debris is a source of extraneous fluorescence. Debris also influences the region to the right of the $G_{1}$ peak (Vindelov \& Christensen 1990).

Fibropapillomas from Hawaii and Florida had CVs of 4.88 and $5.66 \%$ respectively and were at the limits of resolution for distinguishing the presence of abnormal peaks, had they been present. Of the various visceral tumors evaluated, those from the lung, kidney, and liver had normal appearing histograms, with $\mathrm{G}_{1}$ peak CVs $<4 \%$. While 3 stomach tumors also had normal histograms, the mean $\mathrm{G}_{1}$ peak $\mathrm{CV}$ was $6.30 \%$. This high numerical value would preclude discrimination of a peak with a minor DNA-content abnormality, if it were present.

DNA flow cytometry is a gross measurement of DNA content, and abnormalities such as gain or loss of up to several chromosomes are usually not detected by this technique (Merkel et al. 1987). Abnormalities such as translocations, where the overall cellular DNA content is unchanged, also cannot be detected. In a study with slider pond turtles Pseudemys scripta inhabiting seepage basins containing low concentrations of radioactive and non-radioactive contaminants, significantly greater variation in DNA content in blood cells was seen compared to turtles from a control population (Bickham et al. 1988). The authors attributed this difference and the higher mean CV in the experimental population to radiation or chemical-induced chromoso-

Table 4. Chelonia mydas. Green turtles with GTFP from different geographical locations were compared with a 2-way ANOVA of mean CVs (overall F-test, $\mathrm{p} \leq 0.0001$; tissue type, $\mathrm{p} \leq 0.0001$; location, $\mathrm{p}=0.0003$ ). CI: $95 \%$ confidence interval; $\mu$ : mean

\begin{tabular}{|c|c|c|c|c|c|c|}
\hline Sample & Location & $\begin{array}{c}\text { No. of turtles } \\
\text { examined }\end{array}$ & $\begin{array}{l}\text { Mean } G_{1} \\
C V\end{array}$ & $\mathrm{Cl}$ & $\mathrm{SD}$ & $\mathrm{SE}$ \\
\hline \multirow[t]{2}{*}{ Blood } & Florida & 9 & 4.13 & $3.18<\mu<5.07$ & 1.23 & 0.41 \\
\hline & Hawaii Panama & 12 & 2.90 & $2.70<\mu<3.10$ & 0.31 & 0.09 \\
\hline \multirow[t]{2}{*}{ Normal skin } & Florida & 5 & 4.36 & $3.44<\mu<5.28$ & 0.74 & 0.33 \\
\hline & Hawaii, Panama & 3 & 4.50 & $2.02<\mu<6.98$ & 1.00 & 0.58 \\
\hline \multirow[t]{2}{*}{ Fibropapilloma } & Florida & 8 & 5.54 & $4.79<\mu<6.32$ & 1.04 & 0.33 \\
\hline & Hawaii, Panama & 6 & 4.88 & $3.70<\mu<6.07$ & 1.13 & 0.46 \\
\hline
\end{tabular}


mal damage. Evidence of aneuploidy mosaicism was found in 4 of 20 experimental site turtles and supported this contention.

While histograms of dermal scrapings from fibropapillomas had $G_{1}$ peaks with a mean $C V$ significantly greater than that of normal skin and blood from turtles with GTFP, no abnormal peaks were seen in any of the histograms. However the wide $G_{1}$ peak for the fibropapillomas may have masked the detection of an adjacent abnormal peak.

This study indicated that fibropapillomas and visceral tumors have normal cell cycles. The vast majority of the cells examined were in the $G_{1}$ phase. This finding correlates with the histological appearance of the tumor, which has an extremely low mitotic index, is relativeiy aceiiular in the dermal componeni, contains cells with only 1 relatively normal sized nucleus and thus appears to show no indication of malignancy. Since fibropapillomas often occur concurrently at multiple cutaneous sites in the same turtle and also have a visceral component, more than likely the causative agent exerts some systemic influence which results in these multicentric changes. Such a causative agent may exist in the filtered cell-free suspension that was reported to have transmitted GTFP (Herbst et al. 1995, this issue).

Acknowledgements. This study was supported in part by Order No. 43ABNF102091. National Marine Fisheries Service, Southwest Fisheries Laboratory, Honolulu, Hawaii, and Save-A-Turtle, Marathon, Florida. Published as University of Florida Agricultural Experiment Station Journal Series No. 384. The authors thank Dr Anne Meylan for submission of some of the blood samples used in this study and Neal Benson, ICBR Flow Cytometry Laboratory, University of Florida, for technical support

\section{LITERATURE CITED}

Balazs GH (1991) Current status of fibropapillomas in the Hawaiian green turtle, Chelonia mydas. In: Balazs $\mathrm{GH}$, Pooley SG (eds) Research plan for marine turtle fibropapilloma. NOAA-TM-NMFS-SWFSC-156, National Oceanographic and Atmospheric Administration, Honolulu, p $47-57$

Barlogie B, Drewinko B, Schumann J, Gohde W, Dosik G, Johnston DA, Freireich EJ (1980) Cellular DNA content as a marker of neoplasia in man. Am J Med 69:195-203

Benson NA, Braylan RC (1994) Evaluation of sensitivity in DNA aneuploidy detection using a mathematical model. Cytometry 15:53-58

Bickham JW, Hanks BG, Smolen MJ, Lamb T, Gibbons JW (1988) Flow cytometric analysis of the effects of low-level radiation exposure on natural populations of slider turtles (Pseudemys scripta). Arch environ Contam Toxicol 17 : $837-841$

Brooks DE, Ginn PE, Miller TR, Bramson L, Jacobson ER, (1994) Ocular fibropapillomas of green turtles (Chelonia mydas). Vet Pathol 31:335-339

Responsible Subject Editor: $P$. Zwart, Utrecht, The Netherlands
Coulter WH (1956) High speed automatic blood cell counter and cell size analyzer. Proc natl Electron Conf 12: $1034-1042$

Dressler LG, Bartow SA (1989) DNA flow cytometry in solid tumors: Practical aspects and clinical application. Sem Diagn Pathol 6:55-82

Ehrhart LM (1991) Fibropapillomas in green turtles of the Indian River Lagoon, Florida: distribution over time and area. In: Balazs GH, Pooley SG (eds) Research plan for marine turtle fibropapilloma. NOAA-TM-NMFS-SWFSC156. National Oceanographic and Atmospheric Administration, Honolulu, p 59-61

Herbst LH, Jacobson ER, Moretti R, Brown T, Sundberg JP, Klein PA (1995) Experimental transmission of green turtle fibropapillomatosis using cell-free tumor extracts. Dis aquat Org 22:1-12

Jacobson ER (1991) An update on green turtle fibropapilloma. In: Balazs GH, Pooley SG (eds) Research plan for marine turtle fibropapilloma. NOAA-TM-NMFS-SWFSC -1.5h, National Oceanographic and Atmospheric Administration, Honolulu, p 71-73

Jacobson ER, Buergelt C, Williams B, Harris RK (1992) Herpesvirus in cutaneous fibropapillomas of the green turtle Chelonia mydas. Dis aquat Org 12:1-6

Jacobson ER, Mansell JL, Sundberg JP, Hajjar L, Reichmann ME, Ehrhart LM, Waish M. Murru F (1989) Cutaneous fibropapillomas of green turtles (Chelonia mydas). J comp Pathol 101:39-52

Lucké B (1938) Studies on tumors in cold-blooded vertebrates. Rep Tortugas Lab 38:92-92

Melamed MR, Mullaney PF, Shapiro HM (1990) An historical review of the development of flow cytometers and sorters. In: Melamed MR, Lindmo T, Mendelson ML (eds) Flow cytometry and sorting. Wiley-Liss, New York, p 1-9

Merkel DE, Dressler LG, McGuire WL (1987) Flow cytometry, cellular DNA content, and prognosis in malignancy. J Clin Oncol 5:1690-1703

Moldavan A (1934) Photo-electric technique for the counting of microscopical cells. Science 80:188-189

Norton TM, Jacobson ER, Sundberg JP (1990) Cutaneous fibropapillomas and renal myxofibroma in a green turtle, Chelonia mydas. J Wildl Dis 26:265-270

Raber MN, Barlogie B (1990) DNA flow cytometry of human solid tumors. In: Melamed MR, Lindmo T, Mendelson ML (eds) Flow cytometry and sorting. Wiley-Liss, New York, p $745-754$

Schlumberger HG, Lucké B (1948) Tumors of fishes and amphibians and reptiles. Cancer Res 8:657-753

Smith GM, Coates CW (1938) Fibro-epithelial growths of the skin in large marine turtles, Chelonia mydas (Linnaeus) Zoologica NY 23:93-98

Teas W (1991) Sea turtle stranding and salvage network Green turtles, Chelonia mydas, and fibropapillomas In: Balazs GH, Pooley SG (eds) Research plan for marine turtle fibropapilloma. NOAA-TM-NMFS-SWFSC-156, National Oceanographic and Atmospheric Administration, Honolulu, p 89-93

Vindelov LL, Christensen IJ (1990) A review of techniques and results obtained in one laboratory by an integrated system of methods designed for routine clinical flow cytometric DNA analysis. Cytometry 11:753-770

Vindelov LL, Christensen IJ, Nissen NI (1983) Limits of detection of nuclear DNA abnormalities by flow cytometric DNA analysis. Results obtained by a set of methods for sample storage, staining, and internal standardization. Cytometry 3:332-339 